\title{
"Forward and Not Forgetting" - How do Workers' Memories Impact International Solidarity?
}

\author{
Martin Seeliger, Max Planck Institute, Germany
}

\begin{abstract}
Collective remembering in multinational corporations is a field at the intersection of social memory studies and organisational science that has so far been widely neglected within the academic community. Drawing on empirical findings, this article analyses the impact of the organisational memories of South African workers' representatives in processes of cross-border coordination. What is found is that strong ties of international solidarity, dating from the 1970s and 1980s, serve as an interpretative background against which today's situation (which is constituted through different frameworks such as the end of apartheid and economic globalisation) is evaluated critically.
\end{abstract}

\section{KEY WORDS}

Volkswagen, international solidarity, social memory, South Africa, Germany

\section{Introduction}

"Not man or men but the struggling, oppressed class itself is the depository of historical knowledge" (Benjamin, 2007: 260).

As Karl Marx and Friedrich Engels (1959) claim at the beginning of their Communist Manifesto, history unfolds as a struggle between the social classes. While much has been written about both societal developments and the struggles that drive it (Burawoy, 1985), what has been neglected - not least due to a macro-sociological bias in (post-) Marxist labour relations research - are the ways in which actors perceive these temporal dimensions. Drawing on a case of international worker representation, this paper aims to complement this view by reconstructing the perspective of the actors involved. ${ }^{1}$

The impact of social memory on multinational corporations (MNCs) is a field at the intersection of social memory and organisation studies that to date has been largely (if unjustifiably) neglected. As Gabriel (2000: 169) notes, there is "one particular mode in which organizational members seek to make sense of their daily experiences - namely, by juxtaposing them to an organizational past and comparing them [with] it". The object of this study is specifically the meaning of social memory in the coordination of international workers' representation. Drawing on

${ }^{1}$ I would like to thank Barbara Laubenthal, Kati King and two anonymous reviewers for valuable comments and suggestions. 
the case of Volkswagen (VW) we shall describe how workers' memories in South Africa and Germany impact their collective ability to maintain a solidaristic cooperation.

We shall reconstruct three problematic instances in their cooperative relationship over the past fifteen years - a shift to a co-managerial orientation of the works council; a particular strike situation in 1999-2000; and working-time flexibilisation in the course of the economic crisis. Through this process, it can be shown that the memory of the cross-border relationship under apartheid influences contemporary perceptions. These perceptions serve as the interpretative background against which today's relationship is regarded as problematic.

The next section introduces general social scientific insights about cross-border coordination in MNCs and social memory studies, and provides a theoretical framework to be applied to the empirical material. After illustrating the study's methodological conception, the subsequent section introduces the empirical findings. A final section contains some theoretical conclusions and considerations for future research.

\section{Organisational Memory and Coordination of Interest Representation in MNCs}

If organisational activities are shaped by the actions of their members and stakeholders, a sociological perspective needs to give credit to individual perceptions and motivations (Schütz, 1967). Since the interpretation of past events provides us with the experiences necessary to coordinate our action through anticipation of the expectations of others (Mead, 1934), the notion of memory holds a central position in this reconstructive process (Poulton, 2005: 6).

Although both organisation studies (Scott and Davis, 2006) and research on cultural memory (Erll and Nünning, 2008) constitute well-established disciplines, synergetic attempts have emerged only recently. ${ }^{2}$ Although Dawson (2014: 285), in his conceptual overview, justifiably attests to a "poor conceptualization of time" in organisation studies, recent years have brought about a shift in scholarly attention towards issues of temporality (Cropper and Palmer, 2008). While promising conceptualisations have been proposed from a general theoretical angle (for example, Hernes, 2014), to date there has been no systematic consideration of social memory in connection with organisations. Accordingly, Hibbert and Huxham (2010: 525) consider the meaning of memory to be "generally underresearched in organization studies". At the same time, a similar bias towards organisations is acknowledged by Rowlinson et al. (2009) for the field of social memory studies. Drawing on the case of cross-border coordination in MNCs, in the following section we argue that the notion of social memory is crucial in order to understand organisational conduct.

\section{Theoretical Framework - Social Memory and its Impact on Organisations as "Negotiated Orders" in MNCs}

Within the field of organisation studies, Connoly and Dolan (2011: 9) distinguish between two dimensions of the study of organisational memory. First, there is scholarly interest in "the importance of considering the institutional environment when examining organizational change and

2 As two of the few earlier exceptions, see Gabriel (2000) and Walsh and Ungson (1991), as well as the newly established journal Management and Organizational History. 
stability". Berger and Luckmann (1966) have pointed out how institutionalised stocks of knowledge shape the self-concepts and mutual expectations - among other things - of actors. While this knowledge order also serves as a central reference point for the conduct of and within organisations according to a common differentiation (Pries, 2008), organisational units themselves can also be seen as an important dimension of analysis. Accordingly, Walsh and Ungson (1991: 61) understand organisational memory as the amount of "stored information from an organization's history that can be brought to bear on present decisions".

Additionally, there is a standpoint-dependent shape that concrete memories might take depending on who is remembering, and so we must underline the potentially contested character of memories negotiated between various actors (Straub, 2008: 218). Moreover, collective memory does not always provide evidence of the historical causes of current situations. However, the ex-post interpretation of past events becomes strikingly relevant when collective decisions are taken.

As no organisation can durably exist in complete independence from its environment, there is a structural interrelation of collective memory institutionalised in societies' knowledge orders and patterns of organisational memory. Processes of negotiating the implications of perceived past events take concrete shape in the context of social interactions. Accordingly, the institutional setting of a specific frame of reference (for example, a nation state), as well as the concrete organisational context, gain significance as two complementary frameworks within which memories become practically relevant.

When talking about globalisation, MNCs are usually identified as carriers of the development of "a worldwide social relationship which links distinct localities in such a way that local happenings are shaped by events occurring miles away and vice versa" (Giddens, 1990: 64). Reflection on the cross-border activities of MNCs takes place in two academic branches. International business studies (IBS) approach MNCs from an economic perspective, focusing on knowledge transfer as it applies to activities aimed at profit-making in different environments, while a second branch starts from a social science perspective (Sitkin and Bowen, 2010). Second, the field of social science stands out through division of labour between those scholars who focus on management-level analysis and conceptualise worker-representatives as stakeholders (Becker-Ritterspach and Dörrenbächer, 2011), and those focusing on the activities of representatives, such as works councils (Hertwig, Pries and Rampeltshammer, 2009) or international framework agreements (Telljohann, 2009).

While the approaches differ in terms of theoretical framework - a (Marxist) theoretical heritage in the social science literature and a (Smithian) economics background in the field of business studies - a common reference point can be found in the analysis of cross-border coordination. As MNCs operate under different conditions depending on the national setting (Hall and Soskice, 2001), a need for coordination can arise, for example, from differences in national education systems and occupational cultures (Streeck, 2011). Moreover, organisational structure can also be an influential factor in coordination issues (such as relocating the manufacturing of a product within the company network).

Understanding collective memory as "shared by a collective of people with a common cultural identity" (Assmann, 2008: 111) clarifies how this has a crucial meaning for cross-border coordination in MNCs. If national cultures and historically developed knowledge shape perceptions, members from different countries can thus only draw on a body of common experience to the extent that their particular knowledge systems overlap. While original cultural orientations might differ between various subsidiaries, regular interaction might help people to gather enough knowledge about their 
interaction partners to better understand their motives or even contribute to a shared set of values (Festing and Maletzky and Festing, 2011). While cross-border coordination at management level is often institutionalised through regular use of virtual communication technologies, the situation for workers' representatives turns out to be less promising in many cases, for various reasons.

First, the organisational structure of MNCs does not usually designate explicit hierarchies between international workers' representatives. While central management can formulate binding obligations for host-country managers, workers' representatives usually cannot. Although internal management conflicts are not foreign to IBS or social scientific approaches (Dörrenbächer and Gammelgaard, 2011; Rothman and Friedman, 2001), a mutual interest in company profits can be assumed as a common reference point. Second, while subsidiary representatives uphold a more or less constant cooperation with head office representatives, they depend in the first place on their local reference groups - local workers, union organisations and management (Hauser-Ditz et al., 2010). Especially through international competition between subsidiaries, identification with the local workforce is likely to increase further. A third potential reason lies in the relatively scarce resources that labour representatives can use for the purposes of internationalisation.

On a conceptual level, these points illustrate the possible impact of social memory on international workers' representation. The central notion here is the issue of mutual trust: If actors act based on memories, "trust ultimately represents an idiosyncratic accomplishment ... in their stream of experience and interpretation" (Möllering, 2006: 155). A retrospective look at the former working relationship, therefore, serves as a background against which actions are interpreted and chosen. For international workers' representation, a central challenge arises from the embeddedness of the companies' units in different institutional environments. These settings differ not only with regard to their particular history as a development of "objective social facts", but also in terms of the specific interpretations of these histories. The next section illustrates the theoretical approach used to conceptualise this in the inquiry process.

\section{Theoretical Framework: Negotiated Memory Orders in MNCs}

Analysis of social memory in MNCs requires an (at least) twofold perspective on the institutional contexts and the processes of interaction taking place within and between the units. The Negotiated Order approach, developed by Strauss (1978) and others, enables us to take such a perspective. Rejecting the idea of organisations shaped via static structures or fixed internal roles, Strauss emphasises their continuous negotiation through flows of action. The Negotiated Order is thus understood as the

sum total of the organization's rules and policies, along with whatever agreements, understandings, pacts, contracts, and other working arrangements currently obtained. These include the agreements at every level of the organization, of every clique and coalition, and include covert as well as overt agreements (Strauss, 1978: 6).

To analyse the interplay between structural conditions and situated actions, Strauss distinguishes between three dimensions of social life. First, a structural context contains relevant conditions that enable and restrict action capacities found within concrete situations. Accordingly, Maines (1982: 
270) defines the structural context of an organisation as "the larger transcending circumstances in which negotiation contexts exist". This negotiation context can be understood as a framework of social actions characterised by various features (Strauss, 1978: 98f). For the purpose of this research, emphasis will be placed on the balance of power between the parties involved, the respective stakes within the negotiations, the visibility of the transactions pursued by other actors, the number and complexity of the issues that are being negotiated, the clarity or legitimacy boundaries of the issues negotiated and actors' opportunities to opt out of ongoing negotiations. Finally, at the bottom level, the Negotiated Order is constituted through the actions of involved actors. In this dimension, Strauss draws on Shibutani's (1955) concept of social worlds. According to Clarke (1991: 131) these are "groups with shared commitments to certain activities, sharing resources of many kinds to achieve their goals, and building shared ideologies about how to go about their business".

The notion of social worlds points to patterns of interaction and perception within certain social groups. It is within these social worlds that actors develop and transform their perceptions of negotiated issues. For their members, these social worlds thus provide a "structure which permits reasonable anticipation of the behavior of others, [and] hence, an area in which one may act with a sense of security and confidence" (Shibutani, 1951: 566). While social worlds do not only deal with internal issues, but take into account environmental events, opinions and attitudes about issues that might affect their constituency, they are largely formed internally: "Through extended communication, participants in social worlds characteristically generate, adopt, or adapt ideologies about how their work should be done and debate about both their own activities and others' actions that may affect them" (Clarke, 1991: 131-2).

We can thus conclude that social memory comprises particular viewpoints on history rooted in processes of sense-making within particular groups. At the same time, the broader reference frame in which these memories gain their specific meanings is constituted by the broader structural context. In the perspective taken in this article, the structural context comprises both the national settings in which actors are operating and the market situation of the company in general. By reconstructing the interplay of the three levels (structural context, negotiation context and social worlds), the following sections show how social memories influence cross-border coordination among workers' representatives in Volkswagen.

\section{Methodology}

The empirical basis of the study is constituted by data gathered in a research project on international labour regulation at Volkswagen between German headquarters and the South African subsidiary. Between October 2010 and January 2011, sixteen semi-structured interviews were conducted with people from the two countries. These included management officials, members of the local trade unions - Industriegewerkschaft Metall (IG Metall) and the National Union of Metalworkers of South Africa (NUMSA) - and the shop-floor workers' representatives. While most interviews were conducted in the interviewees' offices, one group interview with several shop stewards was carried out in a common room. One representative from NUMSA was met in a restaurant in Johannesburg. At the time all interview partners were employed by the organisations they represented. A total of 17.5 hours of audio material was gathered.

The original point of departure was information provided by a German works council representative, according to whom the working relationship with the South African colleagues was 
somewhat unstable. This instability, according to him, expressed itself, among other things, in unanswered calls to the South African representatives. He also pointed to what he believed to be internal struggles within the South African workers' representative body. Accordingly, the goal of the research was to understand actors' perceptions of mutual cooperation in order to identify possible obstacles to coordinating activities.

\section{Labour Regulation at VW: A German-South African Perspective}

In order to highlight the meaning of social memory for cross-border coordination of workers' representatives in Volkswagen, this section illustrates the various dimensions of the Negotiated Order approach. First, the institutional settings for labour regulation in the two countries will be introduced in order to provide an understanding of the framework conditions that shape local agency. This is followed by a discussion of the negotiation context between the German company and the South African subsidiary, which clarifies the understanding of the framework conditions under which representatives engage in their concrete social interaction.

\section{Structural Context: Labour Relations in Germany and South Africa}

As is widely known, keywords such as "social partnership" or "corporatism" are applied to characterise the German system of labour relations. That system is based on the pillars of general societal wealth and strong welfare institutions, stable negotiation relations between capital and labour, and industrial relations institutionalised in a system of shop-floor and board-related codetermination and collective bargaining. The particular institutional setting of German capitalism not only shapes the overall structures of economic organisation, but comprises the self-understanding of its protagonists - state, capital and labour (Streeck, 2009).

Despite declining membership rates and diminishing collective bargaining coverage, the recent reaction of the social partners to the economic crisis illustrates the flexibility of German labour relations (Thelen, 2013). This trend towards establishing the company level as the primary arena for such decentralisation was initially set in motion in the early 1980s, when IG Metall agreed to negotiate working-time reductions on the shop floor. This trend continued to undermine central agreements through German trade unions agreeing to so-called hardship clauses in the 1990s. Implemented under the Schröder government, the Pforzheimer Agreement of 2004 enables works councils to negotiate wages independently, at lower rates than the regular agreement. Another important element of this flexible regime is the application of flexible working-time arrangements and contract work during the crisis.

At the Uitenhage plant in South Africa, different framework conditions persist. Like practically every other aspect of society, South African labour relations have been shaped by the apartheid system. A high concentration of income and private wealth, combined with a poor education system and relatively little public welfare, have resulted in fairly limited cohesion within South African society. Critics identify a post-colonial regime based on institutionalised oppression of black and coloured citizens: despite all the affirmative action laws, one of the core outcomes of apartheid is the particular interdependence between race and class inequalities found in South Africa: poverty and unemployment are in the first place perceived as "black" and "coloured" problems (Roberts, Kivilu 
and Davids, 2010).

Concerning labour relations and work organisation, the implications are summarised by Edward Webster and his colleagues as an "apartheid workplace regime": "The effects of this regime - low trust, low levels of skill, a reluctance to identify with the goals of the enterprise and, above all, the persistence of the racial division of labour that characterised apartheid - continue into the present" (Webster, Mashilo and Masondo, 2009: 19).

As occupational backgrounds and social mobility have long been structured along racial lines, the field of South African labour relations is not structured by the category of class alone, but also by race and the particular interdependence between the two.

In this context, NUMSA stands out due to its very centralised structure which concentrates power over the affiliated shop-floor representatives. Moreover, a relatively strict socialist orientation leads to what could be called a general "united front" approach that frames collective workers' interests as union interests, which company representatives then have to pursue. As the South African labour movement struggled for decades - and increasingly from the 1960s - to topple apartheid, a particular union culture developed, largely focused on antagonistic and confrontational policies (Bendix, 2010). Because this resistance fostered the broad social involvement of a wide range of actors, the most efficient form of organisation for the unions was centralised structures. While this approach proved historically to be an appropriate way to oppose the apartheid government, the idea of a centralised union remains contested. As the empirical findings show, this counts especially against the background of a progressing shop-floor orientation in MNCs, which relocates the resolution of concrete issues from the trade unions to a company-centred frame.

As a brief comparison of the structural settings in the two countries shows, the framework conditions for labour regulation differ strongly in Germany and South Africa. While the notion of "social partnership" in Germany describes a traditional institutional framework based on general societal wealth and negotiation routines between the parties involved, which involve high levels of mutual trust, the situation in South Africa is still haunted by a "ghost of colonial rule" (Buhlungu, 2010: 194), which makes cooperative relations comparatively improbable. While one core feature of the German system is the mutual trust that shapes management-employee relations, the development of such a bond is very complicated against the background of contemporary power relations in South Africa's economy and society. Based on a comparative illustration, the next section focuses on the negotiation context at VW. Subsequently, three instances of international cooperation among workers' representatives will be introduced, drawing on a social worlds perspective.

\section{Negotiation Context: International Labour Regulation at VW}

The degree of internationalisation found at Volkswagen has been reached by very few corporations. In 2011 (when the research was carried out), VW ran sixty-two subsidiaries in twenty-two countries, twelve of which were located in Germany. Within the international production network, central steering capacities are situated in the powerful headquarters in Wolfsburg.

Volkswagen's involvement in South Africa dates back to 1956, making it the second oldest foreign subsidiary in the country. In 2011 the company employed about 400000 workers, 5000 of whom were working at the South African plant located in the city of Uitenhage in Eastern Cape province. With an average daily production of 650 units, the total value of exports added up to 455 
million Euros in 2008 plus 182 million Euros for components. Against the background of a total turnover of 127 billion Euros in 2010, the economic significance of the South African plant is comparatively low. Given that China and Latin America have become focal points of company engagement (Pries and Seeliger, 2012), recent developments of company internationalisation are also reflected in the amount of attention directed towards claims and issues raised by South African representatives in the company.

VW's works council is probably the most powerful company-level organ of labour interests in Germany. Due to specific legislation that grants the workers an equal share of seats on the company board, a solid working relationship between IG Metall and the works council on the one hand and management on the other has been established over the past decades. Moreover, company internationalisation has since early on been accompanied by an alliance of IG Metall representatives in VW. The Arbeitskreis Internationale Solidarität (InterSoli) was formed in 1982 in order to learn about the situation of colleagues at overseas plants (back then in Mexico, Brazil and South Africa). Subsequently, InterSoli has engaged in a wide range of activities to support Volkswagen workers abroad (for example, charity collections among the German workforce and agenda-setting in the German media, but also through direct action, as in the case of South Africa). Against the background of the recent rounds of European Union enlargement, the main engagement of InterSoli has shifted towards the subsidiaries in central and eastern European countries.

Regarding labour relations at the German subsidiaries, the Volkswagen company particularly stands out due to "a high degree of 'jointness' between management and works councils in company policy, which exceed the formal codetermination framework of industrial relations in Germany (Jürgens, 2002: 10).

As various examples from the past two decades show, this particular model of labour relations has enabled both worker and management representatives to cope with the problems caused by increasing international competition. Measures such as the implementation of flexible working models can thus be understood as compromises that keep production capacities in the home country and help to secure the jobs of German VW workers, who in turn had to make concessions in terms of their wages and working time. Here, a moderating role between management and the workers was taken by the VW works council, as well as by IG Metall on the employee side. This cooperative working relationship is also reflected in measures such as the Volkswagen innovation fund, which grants the works council 20 million Euros per annum to invest independently in R\&D projects to open up new market opportunities for the company (Baum-Ceisig and Osterloh, 2011). It has recently been the ambition of German management and works council to foster such initiatives in the company's overseas plants. Here, an international framework agreement called the Charter of Labor Relations is meant to prospectively grant VW workers the right to exercise plant-level codetermination, similar to the German model (Baum-Ceisig and Osterloh, 2013).

In late 2010, the council consisted of twenty shop stewards. From a legislative perspective, it serves the same purposes as its German counterpart. However, framework conditions give the concrete policies a different shape: while the works council independently influences company policies and interacts at eye level with IG Metall, a clear hierarchy can be identified between the shop steward council at VWSA and NUMSA. Combined with the socialist orientation, the lack of trust between employees and employers, relatively low wages and the anti-capitalist orientation of the centralist union, the framework conditions for negotiating labour policies at the plant often take a more conflictual shape. 
The relationship between German and South African workers' representatives at Volkswagen is far from being a new phenomenon, dating back to the late 1970s, when IG Metall started pushing for measures of international solidarity to support South African workers under apartheid: "Volkswagen is the only automobile company in South Africa where significant long-term relationships developed between the black trade union within the subsidiary and the trade union and works councils in Germany" (Bolsmann, 2007: 107).

In 1980 a delegation of German representatives from the works council organised a trip to Uitenhage. It was this worker-led investigation of South African work and employment conditions that brought the issue of equal treatment onto the agenda of the Wolfsburg-based management. As a consequence, the company took the lead in creating more progressive conditions by, for example, providing occupational training for black craftsmen, beginning in 1981.

As the legitimacy of the racist policies maintained by South African government gradually decreased in the 1980s, struggles against apartheid became more and more intense. Within the broad front of civil society resistance, trade unions continued to play a protagonist role, not least through using the shop floor as an arena for political organisation. Remarkably, working-class alliances in these struggles were not necessarily limited to a local or national frameworks. Especially at Volkswagen, the works council and IG Metall continued with solidarity actions. For example, as head of the works council, Walter Hiller implemented security measures for South African union leader John Gomomo, after receiving death threats from the racist terrorist organisation "White Wolves". Practical solidarity was also exercised through financial support. As the anti-apartheid movement was in large part operating illegally, representatives from the works council and IG Metall established special channels to transfer money into the country, hidden in belts and clothing. This political solidarity was complemented by a close friendship between Gomomo and Hans-Jürgen Uhl, who served as head of the German works council well into the 1990s. As underlined by scholars such as Gumbrell-McCormick (2000: 408) and Bolsmann (2006), at this early stage German support was highly appreciated by the South African workers.

In the course of the 1990s, two developments caused a shift in labour relations at Volkswagen South Africa. While, compared with the rest of the country, the company had for quite some time been pursuing a more equal-treatment-oriented labour policy, the end of apartheid caused a general trend towards more participatory patterns of work organisation (Maller, 1994). Secondly, another factor contributed even more strongly to a shift of German attention away from Uitenhage. While the first parallel production of a series had already been launched in the mid-1980s at the company's Spanish plants, the fall of communism increased the pressure on VW to expand into the central and eastern European labour and consumer markets (Jürgens and Krzywdzinski, 2010).

At the same time, VW intensified its involvement in other regions, such as China and South America. As the German works council had to invest major efforts in the establishment of representative structures at both European and global level, the focal points of workers' representation shifted.

These developments in the company's new integrated production network also affected the situation at VWSA. With regard to recent history after the end of apartheid, we can identify three clusters of problems in which this constellation has led to tensions between German and South African labour representatives. For example, the latter complained about a lack of solidaristic support from the Germans. At the same time, German labour representatives who were trying to play a moderating role between South African workers' representatives and management showed 
signs of frustration, referring to the mainly antagonistic positions of their South African colleagues. As will be shown, the perception of the relationship under apartheid shaped expectations in a way that has made cooperation a frustrating experience for the southern colleagues.

\section{Co-management as a reaction to international competition}

A first area in which frictions in international cooperation occurred is the reactions to increased international competition. Here, starting with the so-called China Export Agreement in 1992, there was a threefold impact (Bolsmann, 2006: 173) on labour regulation at VWSA. First, reference to international competition within the company's production network became a regular part of the discourse on labour regulation at the plant. Second, a general flexibilisation of work organisation increased pressure on the workforce. Third, the creation of additional jobs at the plant was related to measures to cut labour costs.

As described above, the German reaction to this new constellation comprised an overall turn towards co-managerial policies, pursued by the works council and IG Metall. A similar orientation among South African representatives was ruled out by a NUMSA official from the Johannesburg headquarters. According to him, alliances with management cannot be in the interest of a trade union:

Our approach is that management [always acts in its own interests]. But [at] NUMSA, our understanding is that a trade union is reactionary in nature ... a trade union that [attempts to be proactive will never get the better of the situation]. Because as a trade union you always react to what has been given to [you].

Accordingly, as one shop steward states, the German approach is regarded with some scepticism by the South African colleagues. Here, the suspicion is raised that focusing too much on company policies results in the abandonment of broader working class interests.

With the works council representatives, we used to suspect that they were looking more at the interests of the company than of the union. [...] Because ... the works council has some limitations, you know. Sometimes they want to keep certain information confidential. Sometimes they have to... because they have access to information about their corporation.

Among the German interviewees - especially those from the works council - a similar criticism is directed at the centralist structures of NUMSA, which - according to them -would impede effective negotiation outcomes with South African management. Moreover, NUMSA representatives are not willing to make any concessions, aiming to keep production at the plant. The idea of the works council representative on how to organise workers' representation under conditions of increasing competition is as follows:

If you're asking, 'how do I get a production order to Uitenhage?', then you need to ask 'how can I make the car cheaper? How can I organise production intelligently?'

He explains the co-management approach pursued by the works council as follows: 
If I consider what kind of work we as works council and IG Metall are doing every day, it is entrepreneurial, managerial work. We're managing workers' interests, that's what we like to call it.

An example of the difficulties that may arise from these diverging approaches can be found in an initiative put forward at the recommendation of the German works council. In order to secure the existence of the Uitenhage plant for the coming years, the German works council negotiated with management to allocate significant investment into a paint shop. As this modernisation measure was to be accompanied by job cuts, heavy resistance by NUMSA successfully blocked the initiative for a good while. At the same time, the involvement of the Germans is not valued, but described by the NUMSA official as indifferent to the interests of working-class members beyond their own company.

Yes, we have shared perspectives about the economic and political situation. But there is no way that we discuss the politics of the working class. They don't seem interested. Although they are very interested in issues concerning the corporation.

As the incidents indicate, together with the perspectives taken from the interviews, the South African trade unionists are not willing to adopt market logic into their political repertoire. While German representatives have long been engaging in co-managerial policies, such orientations cause scepticism among the South African colleagues. A similar divergence of perspectives can be found in the negotiation of major industrial action that took place at between 1999 and 2000.

\section{The Uitenhage strike, 1999-2000}

As an immediate consequence of international competition in the course of globalisation, the abovementioned China Export Agreement has served as a starting point for an ongoing negotiation process between NUMSA and local management. With the official aim of "restructuring production to meet targets" (Buhlungu, 2008: 103), various rationalisation measures were to be implemented, including speeding up the assembly line, shortening tea breaks and extra pay for overtime on weekends. After local NUMSA representatives had finally agreed to accept the cuts, events culminated in a labour conflict that lasted from 1999 to 2000. A significant number of workers carried out a wildcat strike against the recommendation of the union. After repeatedly refusing to go back to work, 1386 employees were dismissed by the company.

What seems remarkable about the strike situation is the fact that the central cleavage line did not run between capital and labour, but within the labour movement itself: "What makes the strike both fascinating and perplexing is the fact that it arose out of a dispute within the union, and one section of the membership embarked on the strike, not against Volkswagen South Africa management but against union leadership" (Buhlungu, 2008: 93).

That estimation is shared by Webster et al. (2009: 37), according to whom the "strikers felt betrayed by their own union which, in their view, was deviating from the historical tradition of worker control and internal democracy".

This complexity is also reflected in the variety of explanations found in the literature. 
Buhlungu (2008) identifies a general democracy deficit inside the union. As the NUMSA leadership had initially agreed to the rationalisation measures, it had lost its legitimacy among the members. Similarly, Forrest (2000) finds a general alienation of the shop-stewards council from the workforce. An even stronger argument is made by Bolsmann (2010), who claims complicity between NUMSA and the capital side.

Despite the complexity of the local constellation, the German works council and IG Metall attempted to mediate between the parties, sending delegates to Uitenhage and Johannesburg. While he states that the initiative was generally welcomed, one of the shop stewards explains his problem with the mediation strategy:

Yes, it's very difficult. We had some problems, because comrades from Germany, or colleagues from the German works council would come and spend most of their time with management in South Africa. Not with us as a union. We [have] had problems.

In the perspective of the South African colleagues, the behaviour of the German delegates seems problematic for two reasons. First of all, in a situation of internal instability and disorder, the intense contact of the Germans with local management appears suspicious (especially against the background of the general proximity between the German works council and management). In addition to the concrete political implications of such an alliance, the German focus on management contacts is also regarded as containing a personal affront.

\section{The fight over flexible working-time arrangements during the crisis}

A third cause of differences between ideas of representative work lies in the introduction of flexible working-time arrangements during the economic crisis of 2008-2009. As pointed out above, the application of working-time accounts has enabled German social partners to maintain production and protect employment (at least among core employees).

Aiming to even out changes in demand brought about by the crisis, local management proposed the implementation of a similar model in Uitenhage, which was strongly opposed, especially by NUMSA. The most controversial aspect of this proposal was a change in the overtime regulation. Here, the usual addition of 50 per cent of the regular wage was no longer to be compensated financially. Instead of receiving money, the additional labour would be transformed into bonus time stored in a virtual account.

In order to understand the different perspectives on working-time accounts, it is not sufficient to refer to the different traditions of representative work. Instead, it must be noted that these measures were taking place against the background of the particular institutional settings in toto. In contrast to the German situation, poor living conditions in the Eastern Cape region - due to high unemployment, household debt and the absence of sufficient welfare institutions - mean that, on average, 5.6 people depended on the job of one Volkswagen worker (Webster et al., 2009: 48).

These discrepancies, stemming from both economic framework conditions and particular political orientations, can clearly be identified in a heated debate about working-time accounts, which took place between local management, NUMSA and the shop stewards' council. Dissatisfied with the solution, NUMSA representatives forced the shop stewards to resign. Besides the general concern about losing power to the shop-floor level, this stance taken by the union again corresponds to their 
idea of management's and workers' responsibilities. As one of the NUMSA representatives explains, reactions to the international market situation in the crisis cannot legitimately be expected from the employees' side:

If the global market situation brings sales problems, these are management problems. But we are responsible for the workers' interests, not management interests.

As is apparent in the quotes from the interviews with the works council, the attitude expressed by the NUMSA official is not compatible with the approach pursued by the German colleagues. From the South African perspective, their refusal to accept a flexible working-time regulation, connected with a threat to go on strike against it, is a symbol of strength and resolve towards the company, regardless of its economic implications. As one German representative states, attempts to mediate between the local parties have been ignored by both the local trade union officials and colleagues in Johannesburg.

\section{The impact of social memory on international cooperation}

Based on the three instances sketched out above, we shall argue that the central difficulty of the working relationship between German and South African representatives is the memory of what cooperation was like until the early 1990s. The shop stewards in particular criticise a lack of attention to Uitenhage on the part of the German colleagues. According to them, the only occasions at which they can explain what is going on at their plant are the bi-annual meetings of VW's world works council. Unfortunately, due to their limited timeframe and the number of issues at stake within the global production network, these meetings do not provide an opportunity for mutual exchange. As several shop stewards point out, in the past such exchanges took place on a bilateral basis, not least through personal contacts. This is also highlighted by a representative from IG Metall, who has cooperated with the South African colleagues since the 1990s:

Since the death of John Gomomo and the departure of Hans-Jürgen Uhl, there have been no more close relationships. It was not only the breakdown of mutual trust through the conflicts. It was the irreplaceability of this great friendship between them.

Similar references to the relationship between the two can also be found in interviews with shop stewards and NUMSA officials. Moreover, anecdotes about concrete actions of international solidarity, such as the smuggling of money for the anti-apartheid struggle or mutual visits, when officials from both countries were invited to stay for several weeks with the families of local colleagues, serve to illustrate the quality of the good relationship in the past.

Today, as one NUMSA colleague confirms, such contacts do not exist:

No, it's not the same. We don't get to meet IG Metall, after InterSoli. Or it has disappeared. We used to meet with IG Metall during InterSoli. In the InterSoli era we did get to meet IG Metall.

Differentiating the current situation from the past, a NUMSA representative gives credit to the 
German representatives from the works council as well as from IG Metall for their support for the struggle against apartheid:

Yes, remember, before the era of globalisation it was easy. But now there is all this free trade and things have changed. During apartheid, because of IG Metall, we managed to keep our shop stewards paid by the company even while in prison. In meetings in German companies, the police could not come and get us. But sometimes when they knew there were shop stewards they went straight inside the factories to get hold of them. But [they] paid ... legal fees for shop stewards. [They] also paid them wages while they were in prison. But now, because of globalisation, things have changed, you know, because of free trade and other things.

While similar credit is given by one of the shop stewards, he also refers to the shift in the provision of such supporting measures, which, according to him, strongly decreased after the defeat of apartheid:

Yes, under apartheid the solidarity group was very vocal. You see, with other people who were working here during the 1980s, they used to be detained. Because we had strong links with InterSoli. When they come back to visit, VW will not dismiss them. Because they were in the course of liberating this country. Some will spend years but when they come back, they will be reinstated. This is what we had strongly expected. But since we're free, this thing is not really continuing.

In this sequence a strong interpretative contrast is constituted through the dichotomous perceptions of past and present in the eyes of the shop steward. To conclude this section we show how this is to be interpreted in relation to the question of cross-border coordination among international workers' representatives in connection with social memory.

\section{Summary of the empirical findings}

As the three instances of international cooperation and their problematic implications indicate, local framework conditions in the two countries complicate mutual understanding as a precondition for a shared political position. German and South African representatives seem to choose their political demands in close connection to the respective institutional settings. While an interest-based explanation would highlight the fact that preferences derive from these particular framework conditions, the empirical material shows that a simple reference to these national institutional settings cannot fully explain the relationship between the national representatives.

The interviews with the South African representatives show that experiences of past cooperation with IG Metall in joint solidarity against the apartheid regime still constitute the interpretative framework applied to make sense of contemporary cooperation. For example, the perception that German delegates decided to spend significant time with management in order to resolve the strike situation shows that the relationship between the national representatives is based on more than pure interest representation. Instead, the irritation of the South African colleagues goes beyond a purely interest-based view. Similarly, what seems to be at stake in the discussion about 
co-management or the introduction of flexible working time models is not just the question of how close the relationship between employers and employee representatives should be. Instead, these issues become instances of realising and negotiating working-class identity.

As we have shown, social memory plays a crucial role in these negotiation processes. In the sequences quoted from the interviews, references to such experiences as the friendship of Uhl and Gomomo or the illegal transfer of money from Germany to South Africa become a wildcard for

"the good old times", when mutual understating served as a solid basis for international cooperation. While it may well be that co-managerial arrangements translate into a model of workers' representation that is undesirable for the South African colleagues, from an interest-based perspective these discrepancies become especially virulent in terms of their perception against the background of the past.

\section{"Forward, without Forgetting" - Social Memory and International Workers" Representation}

Drawing on a case of international workers' representation, this study has addressed the question of how workers' memories in South Africa and Germany impact their collective ability to maintain solidaristic cooperation. Because sequences of coordinated action in a world of socialised actors never start from scratch but are instead made up of ongoing sequences of action, perceptions of the past play a crucial role in the systematic understanding of actions (and thus, in organisations).

Drawing on the Negotiated Order approach, it could be shown how social memory serves as an orientation among the groups involved in international workers' representation at Volkswagen. As the social world perspective reveals, negotiation processes are here embedded in transnational constellations. While this finding might not appear very surprising for the case of MNCs, it should be taken into account that organisational memories still acquire their particular shapes within national boundaries. While the German institutional setting of social partnership clearly influences the idea of labour regulation as a co-managerial process, framework conditions in South Africa cause the local representatives to take a much more antagonistic position. As could be shown, it is exactly at this point that social memory works as an obstacle to mutual understanding. With the question of "temporal effects of coordination between actors with different historicities and ambitions at different locations" (Hernes, 2014: X) at the core of the future research agenda of organisation studies, these insights might serve as a programmatic contribution in this regard.

Given the potential value of considering social memory in the cross-border coordination of labour politics, as shown in the case study, we can now ask about the implications for global labour studies in more general terms. Departing from the work of Karl Polanyi (1957), a recent debate in this journal (Burawoy 2010) centred around the potential of a global countermovement, complementing the globalisation of capital through the establishment of effective regulations. While it has been argued that international cooperation among workers' representatives could eventually lead to what Pries and Seeliger (2013) termed an "international network texture of labor regulation", ambivalences in this development must be taken into account, as well. If cross-border coordination implies, for example, an insistent demand for the South African representatives to adopt comanagerial patterns that (seemingly) privilege the shop-floor level at the cost of the central trade union structures, can we still speak of a general strengthening of workers' counter-power? 
A central challenge for both global labour studies and the protagonists of the global labour movement, I would argue, is to take into account the ambivalences and contradictions inside this countermovement. While internal diversity is not necessarily a weakness for international labour (Gumbrell-McCormick and Hyman, 2013), in order to access this diversity as a potential resource for strategic action, it will be necessary to show a great deal of sensitivity towards the local backgrounds. "Forward without forgetting!" - while originally referring to working-class power stemming from solidaristic cohesion in general, the chorus of the famous solidarity song by Berthold Brecht and Hanns Eissler can alternatively be read along the lines of the questions addressed in this article. The emergence of transnational cultures of memory in such international contexts has the potential to help democratise and strengthen the working class throughout the world.

\section{REFERENCES}

Assmann, J. (2008) Communicative and Cultural Memory. In Cultural Memory Studies, edited by A. Erll and A. Nünning. Berlin and New York: Walter de Gruyter.

Baum-Ceisig, A. and B. Osterloh (2011) Wirtschaftsdemokratie in der Praxis In Mehr Wirschaftsdemokratie wagen! edited by H. Meine. Hamburg: VSA.

Baum-Ceisig, A. and B. Osterloh (2013) Mitbestimmung im Volkswagen-Konzern. In Arbeit, Organisation, Mobilität, edited by M. Maletzky et al.. Frankfurt a.M.: Campus.

Becker-Ritterspach, F. and C. Dörrenbächer (2011) An Organizational Politics Perspective on Intrafirm Competition in Multinational Corporations. Management International Review, 51(4): 53359.

Bendix, S. (2010) Industrial Relations in South Africa. Cape Town: Juta.

Benjamin, Walter (2007) Theses on the Philosophy of History. In Illuminations, edited by Benjamin Walter. New York: Schocken.

Berger, P.L. and T. Luckmann (1966) The Social Construction of Reality. Garden City: Anchor Books.

Bolsmann, C. (2006) Trade Union Internationalism and Solidarity in the Auto Industry. Unpublished $\mathrm{PhD}$ thesis, University of Warwick, United Kingdom.

Bolsmann, C. (2007) Trade Union Internationalism and Solidarity in the Struggle against Apartheid. Historical Studies in Industrial Relations, 23/24(1): 103-24.

Bolsmann, C. (2010) Contesting Labour Internationalism: The "Old" Trapped in the "New" in Volkswagen's South African Plant. Labor Studies Journal, 4(12): 520-39.

Buhlungu, Sakhela (2008) The Rise and Decline of the Democratic Organizational Culture in the South African Labor Movement, 1973 to 2000. Labor Studies, 34: 91-111.

Buhlungu, Sakhela (2010) Trade Unions and the Politics of National Liberation: An Appraisal. In Trade Unions and Party Politics: Labour Movements in Africa, edited by B. Beckman et al. Cape Town: HSRC Press.

Buhlungu, Sakhela et al. (2008) Trade Unions and Democracy in South Africa. British Journal of Industrial Relations, 46(3): 439-68.

Burawoy, Michael (1985) The Politics of Production. London: Verso. 
Burawoy, Michael (2010) From Polanyi to Pollyanna: The False Optimism of Global Labour Studies. Global Labour Journal, 1(2): 300-13.

Clarke, A. (1991) Social Worlds/Arenas Theory as Organization Theory. In Social Organization and Social Process, edited by David R. Maines. New York: Aldine de Grumer.

Connoly, J. and P. Dolan (2011) Organizational Centralization as Figurational Dynamics: Movements and Counter-movements in the Gaelic Athletic Association. Management and Organizational History, 6(1): 37-58.

Cropper, S. and I. Palmer (2008) Change, Dynamics, and Temporality in Inter-organizational Relationships. In The Oxford Handbook of Inter-Organizational Relations, edited by Steve Cropper et al. Oxford: Oxford University Press.

Dawson, P. (2014) Reflections: On Time, Temporality and Change in Organizations. Journal of Change Management, 14(3): 285-308.

Dörrenbächer, C. and J. Gammelgaard (2011) Conflicts in Headquarters-Subsidiary Relationships. In Politics and Power in the Multinational Corporation: The Role of Institutions, Interests and Identities, edited by M. Geppert and C. Dörrenbächer. London: Routledge.

Erll. A. and A. Nünning (eds) (2008) Cultural Memory Studies. Berlin and New York: Walter de Gruyter.

Festing, M. and M. Maletzky (2011) Cross-Cultural Leadership Adjustment: A Framework based on the Theory of Structuration. Human Resource Management Review, 21(3): 186-200.

Forrest, K. (2000) What happened at VW? South African Labour Bulletin, 24: 20-22.

Gabriel, Y. (2000) Storytelling in Organizations. Oxford: Oxford University Press.

Geppert, M. and C. Dörrenbächer (2011 Politics and Power in the Multinational Corporation: The Role of Institutions, Interests and Identities, edited by M. Geppert and C. Dörrenbächer. London: Routledge.

Giddens, A. (1990) The Consequences of Modernity. Cambridge: Stanford University Press.

Gumbrell-McCormick R. (2000) Facing New Challenges: The International Confederation of Free Trade Unions (1972-1990s). In The International Confederation of Free Trade Unions, edited by A. Carew et al. Frankfurt am Main: Peter Lang.

Gumbrell-McCormick, R. and R. Hyman (2013) Trade Unions in Western Europe. Choices. Oxford: Oxford University Press.

Hall, P. and D. Soskice (2001) Varieties of Capitalism. Oxford: Oxford University Press.

Hauser-Ditz, A., M. Hertwig, L. Pries and L. Rampeltshammer (2010) Transnationale Mitbestimmung? Frankfurt am Main and New York: Campus.

Hernes, T. (2014) A Process Theory of Organization. Oxford: Oxford University Press.

Hertwig, M., L. Pries and L. Rampeltshammer (eds) (2009) European Works Councils as International Non-profit Organisations. Brussels: ETUI.

Hibbert, P. and C. Huxham (2010) The Past in Play. Organization Studies, 31(5): 525-54.

Jürgens, Ulrich (2002) Corporate Governance, Innovation, and Economic Performance. Available online at .http://bibliothek.wz-berlin.de/pdf/2002/ii02-205.pdf (accessed 15 February 2012).

Jürgens, Ulrich and Martin Krzywdzinski (2010) Die neue Ost-West-Arbeitsteilung. Arbeitsmodelle und 
industrielle Beqiehungen in der europäischen Automobilindustrie. Frankfurt am Main and New York: Campus.

Maines, David R. (1982) In Search of Mesostructure. Journal of Contemporary Ethnography, 11(3): 26779 .

Maller, Judy (1994) Worker Participation and Trade Unionism: Case Studies of Workplace Democracy in South Africa. Economic and Industrial Democracy, 15: 241-57.

Mead, G.H. (1934) Mind, Self, and Society. Chicago: University of Chicago Press.

Marx, K. and F. Engels (1959) Manifest der Kommunistischen Partei. In MEW 4. Berlin: Dietz.

Möllering, G. (2006) Trust: Reason, Routine, Reflexivity. Oxford: Elsevier.

Polanyi, K. (1957) The Great Transformation. Boston: Beacon Press.

Poulton, M.S. (2005) Organizational Storytelling, Ethics and Morality. Electronic Journal of Business Ethics and Organization Studies, 10(2).

Pries, L. (ed.) (2008) Retbinking Transnationalism. London: Routledge.

Pries, L., and M. Seeliger (2012) International, flexibel und mit Tendenzzum Greening? Arbeits- und Industriesoziologische Studien, 5(2): 80-97.

Pries, L. and M. Seeliger (2013) Work and Employment Relations in a Globalized World. Global Labour Journal, 4(1): 26-47.

Roberts, B., M.W. Kivilu and Y.D. Davids (eds) (2010) South African Social Attitudes. Cape Town: HSRC.

Rothman, J. and V. Friedman (2001) Identity, Conflict and Organizational Learning. In Handbook of Organizational Learning and Knowledge, edited by M. Dierkes, A.B. Antal, J. Child and I. Nonaka. New York: Oxford University Press.

Rowlinson, M., C. Booth, P. Clark, A. Delahave and S. Procter (2009) Social Remembering and Organizational Memory. Organization Studies, 31(1): 69-87.

Schütz, A. (1967) The Phenomenology of the Social World. Evanston, IL: Northwestern University Press.

Scott, W. and G.F. Davis (2006) Organizations and Organizing. Upper Saddle River: Prentice Hall.

Shibutani, T. (1955) Reference Groups as Perspectives. American Journal of Sociology, 60(6): 562-9.

Sitkin, Alan and Nick Bowen (2010) International Business. Oxford: Oxford University Press.

Straub, J. (2008) Psychology, Narrative and Cultural Memory. In Cultural Memory Studies, edited by A. Erll and A. Nünning. Berlin and New York: Walter de Gruyter.

Strauss, A. (1978) Negotiations. San Francisco: Jossey-Bass.

Streeck, Wolfgang (2009) Re-Forming Capitalism. Oxford: Oxford University Press.

Streeck, W. (2011) Skills and Politics. Available online at http://www.mpifg.de/pu/dp abstracts/dp111.asp (accessed 18 August 2012).

Telljohan, V. (2009) European and International Framework Agreements Report. Dublin: European Foundation for the Improvement of Living and Working Conditions.

Thelen, K. (2013) Varieties of Liberalization. Cambridge: Cambridge University Press. 
Walsh, J. and G. Ungson (1991) Organizational Memory. Academy of Management Review, 16(1): 57-91.

Webster, E., A. Mashilo and T. Masondo (2009) Changes in Production Systems and Work Methods. Johannesburg: NUMSA/FES/SWOP.

\section{BIOGRAPHICAL NOTE}

MARTIN SEELIGER wrote his PhD on European Trade Unionism at the Max Planck Institute for the Study of Societies in Cologne, where he currently works as a post-doc. After majoring in Social Science at the Ruhr University of Bochum, he was a visiting fellow at the Sociology Department of the Universidad Autónoma Metropolitana, Mexico City, the European Trade Union Institute in Brussels, the Stockholm Center for Organizational Research, and the Charles and Louise Travers Department of Political Science in Berkeley, where he studied international labour relations from a perspective informed by elements from American Pragmatism and sociological institutionalism. [Email: martin.seeliger@gmx.net] 